\title{
Features of evaluating the efficiency indicators of the electric power enterprise
}

\author{
$O V$ Novikova $^{1, *}, A E$ Erastov $^{2}$ and $S A$ Livshits $^{3}$ \\ ${ }^{1}$ Department of nuclear and thermal energy, Peter the Great St. Petersburg Polytechnic University, Politekhnicheskaya, 29, Saint- \\ Petersburg, 195251, Russia \\ ${ }^{2}$ Department of energy sales and energy saving, Petersburg power engineering institute of professional development, Aviacionnaya, 23, \\ Saint-Petersburg, 196135, Russia \\ ${ }^{3}$ Kazan State Power Engineering University, Krasnoselskaya, 51, Kazan, 420034, Russia
}

\begin{abstract}
The electric power industry is at the dynamic development stage, which is accompanied by reconstruction and modernization of fixed assets. It is necessary to understand that this process leads to the risks that the company will bear in the innovative projects implementation. In this regard, the issues on electric power enterprise efficiency management are relevant. In addition, in market economy, the factors of both external and internal environment can affect the efficiency of an enterprise. The set of these factors, as well as the strength of their influence can vary depending on the industry and enterprise's activities. In this regard, the purpose of this study is to formulate a system of recommendations for managing the efficiency of an electric power enterprise. The object of research is the electric power enterprise of IDGC of the NorthWest, PJSC. The result of the study is an econometric model, which describes the influence of external and internal factors on the electric power enterprise efficiency. The recommendations developed on the basis of this econometric model are relevant for the construction of strategies and management systems for the efficient operation of electric power enterprises.
\end{abstract}

\section{Introduction}

In market economy, consideration of external and internal factors of the economic environment is required to assess the financial stability of the enterprise, as well as the efficiency of its resources.

Ensuring the strategic sustainability of electric power companies is the most important task of the Russian economy. The reason is that the functioning and development of the basic sectors of the national economy in many ways depend on the efficiency and effectiveness of the domestic electric power industry.

The object of the study is the electric power company IDGC of the North-West, PJSC. Currently, the power industry is at the stage of active development, accompanied by introduction, modernization and reconstruction of fixed assets. Implementing innovative projects is necessary to understand the risks that the organization will incur. That is why creation of a mechanism to improve the efficiency of the enterprise explains the relevance of the topic in this area.

The subject of the study is the enterprise efficiency, expressed in the coefficients of own capital profitability, profitability on assets, sales and costs.

The aim of this study is to develop a system of recommendations to improve the efficiency of the electric power enterprise.
To achieve this aim it is necessary to solve the following tasks:

- To study the theoretical basis of energy enterprise efficiency;

- To determine the performance indicators of the energy enterprise;

- To identify external and internal factors that affect the performance of the enterprise;

- To create an econometric model of relationship between performance indicators and the factors of internal and external environment;

- To analyze the results and make a conclusion.

To study the impact of the internal environment on the enterprise efficiency, we selected financial stability coefficients based on the characteristics of the specific organization of ROSSETI JSC. The coefficients are calculated based on the balance sheet.

Factors that do not have a direct impact on the activities of the organization, but should be taken into account to develop the right strategy, were chosen as external signs-factors (indicators). These include: the level of inflation, the refinancing rate, the population, the average wage in Russia, the number of apartments in Russia.

The procedure for constructing the final version of the model is based on the following steps:

- All factors selected in the substantive analysis of the problem are included in the initial version of the

\footnotetext{
* Corresponding author: novikova-olga1970@yandex.ru
} 
model. For this option, the values of correlation coefficients, determination and normalized determination coefficient, p-values, and F-criterion are calculated;

- The insignificant factor that has the greatest $\mathrm{p}$ value is removed from the model. Thus, a new version of the model with reduced number of factors by one is formed;

- The factor selection process can be considered complete when the remaining factors in the model are significant. If the resulting version of the model matches other criteria of its quality, the process of making the model can be considered complete as a whole.

\section{Analysis of the impact of internal factors}

To identify the relationship between the performance indicators of IDGC of the North-West, PJSC and internal indicators, a multiple regression model was built.

The following performance indicators were selected as the resulting variables [1-6]:

- $\quad$ Y1 -The own capital profitability;

- $\quad \mathrm{Y} 2$ - The profitability on assets;

- $\quad$ Y3 - The profitability on sales;

- $\quad$ Y4 - The profitability on costs.

The following key indicators of financial stability of the enterprise were selected as dependent variables $[1,7-$ 9]:

- $\quad \mathrm{X} 1$ - The capital productivity;

- $\quad \mathrm{X} 2$ - The autonomy ratio;

- $\quad \mathrm{X} 3$ - The asset turnover ratio;

- $\quad$ X4 - The ratio of own funds;

- $\quad$ X5 - The debt to equity ratio;

- X6 - The ratio of accounts receivable to accounts payable.

The calculation showed that the selected set of indicators fully explains only the variation of return on the own capital profitability of the company, in other cases the treatment does not take into account a number of factors that could explain the variation of the resulting indicators.

\section{Analysis of the external factors influence}

To identify the relation between the performance indicators of IDGC of the North-West, PJSC and the indicators of the external environment, a multiple regression model was built. The following indicators were selected as dependent variables [1-4, 10-13]:

- $\quad \mathrm{X} 1$ - The level of inflation;
- $\quad \mathrm{X} 2$ - The refinancing rate;

- $\mathrm{X} 3$ - The population;

- $\quad \mathrm{X} 4$ - The average wage in Russia;

- X5 - The number of apartments in Russia.

The treatment of the impact of environmental indicators on the performance indicators of IDGC of the North-West, PJSC showed that the selected set of indicators does not fully explain the variation in performance indicators. Also, the treatment revealed that the efficiency of the enterprise does not depend on the macro environment and is determined solely by the factors of the internal environment. In this case, the analysis does not provide objective information about the possible losses of the enterprise in the event of an unforeseen situation in the Russian economy.

\section{The final model of profitability of sales}

Since the efficiency of the enterprise is influenced by factors of external and internal environment, it is necessary to build a model that would take into account their full set. The simulation results are presented in table 1 .

Table 1 shows that in this case, the multiple correlation coefficient, which describes the close relation between return on equity and a set of factors of the internal environment, is 0.999. In accordance with the Cheddock scale it characterizes a strong relation.

Table 1.Characteristics of the multiple regression model.

\begin{tabular}{|c|c|}
\hline Multiple R & 0.99907 \\
\hline R-square & 0.99814 \\
\hline Normalized R-square & 0.99258 \\
\hline Standard error & 0.25233 \\
\hline Multiple R & 0.99907 \\
\hline
\end{tabular}

The normalized coefficient of determination also indicates that the selected set of factors by $99.2 \%$ explains the variation in the profitability of sales of IDGC of the North-West, PJSC.

The regression equation is as follows:

$$
\begin{aligned}
& Y=-96.61+5.71 * X 1+1.79 * X 2+1.17 * X 3 \\
& -1.93 * X 4+1.37 * X 5-1.97 * X 6
\end{aligned}
$$

This equation is statistically significant, F-criterion $=$ 179.507 , and the average approximation error is $7 \%$.

The dependence in the residuals is absent, i.e., deviation values of the profitability of sales are random, which is demonstrated in Figure 1.

The values of profitability of sales ratios are within the confidence intervals (Figure 2).

Table 2. The elasticity coefficients.

\begin{tabular}{|c|c|c|c|c|c|c|}
\hline & $\begin{array}{c}\text { Autonomy } \\
\text { ratio }\end{array}$ & $\begin{array}{c}\text { Asset turnover } \\
\text { ratio }\end{array}$ & $\begin{array}{c}\text { Level of } \\
\text { inflation }\end{array}$ & $\begin{array}{c}\text { Refinancing } \\
\text { rate }\end{array}$ & Population & $\begin{array}{c}\text { Number of apartments } \\
\text { in Russia }\end{array}$ \\
\hline $\begin{array}{c}\text { Elasticity } \\
\text { coefficient }\end{array}$ & 4.88 & 2.81 & 1.99 & 24.49 & 300.69 & -186.88 \\
\hline
\end{tabular}




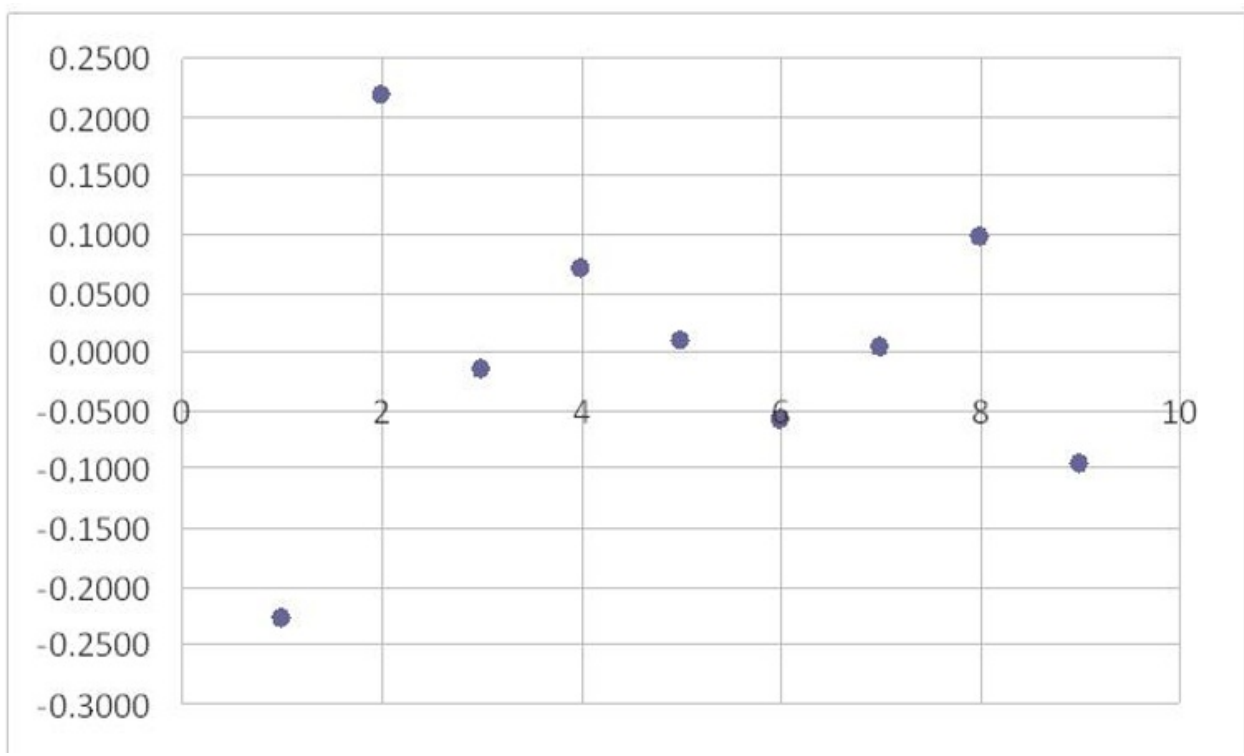

Fig. 1. Distribution of the residues of the profitability of sales.

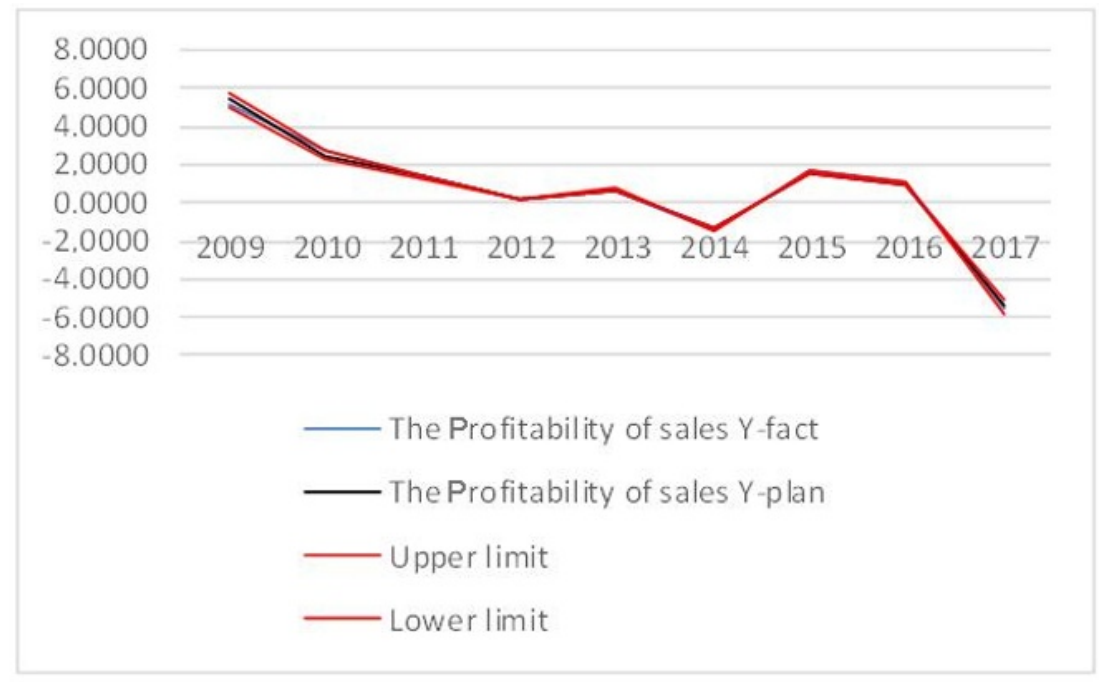

Fig. 2. The boundaries of the interval of the profitability of sales.

To compare various coefficients of the equation, we will use the relative strength of the relation - the elasticity coefficient, which shows how to change the result when you change the factor to $1 \%$. The calculated values of the elasticity coefficients are presented in table 2.

The table shows that with an increase in the coefficient of autonomy by $1 \%$, the profitability of sales will increase by $4.88 \%$. If the asset turnover ratio increases by $1 \%$, the profitability of sales will increase by $2.81 \%$. This fact is explained by the direct relation between the indicators of the profitability of sales and the asset turnover, as the growth of the profitability of sales and the acceleration of asset turnover lead to an increase in return on assets as a whole and vice versa. With the inflation rate increasing by $1 \%$, the profitability of sales will increase by $1.99 \%$. This fact can be explained by changes in the pricing policy of the organization taking into account the risk of inflation. If the refinancing rate changes by $1 \%$, the profitability of sales will increase by $24.49 \%$. With the population increase of $1 \%$, the profitability of sales will increase by $300.69 \%$. With a decrease in the number of apartments by $1 \%$, the profitability of sales will decrease by $186.88 \%$. It is logical to talk about the direct dependence of the growth in the number of population and apartments on the profitability of sales of the energy enterprise, as with their increase, the need for electricity increases, therefore, the sales volume increases and vice versa.

Thus, the presented model is not only statistically significant, but also takes into account the influence of external and internal factors on the profitability of sales of IDGC of the North-West, PJSC. This model can be used for forecasting. 


\section{Conclusion}

Thus, the profitability of sales is influenced by both external and internal factors.

The explanation of the coefficient of autonomy influence can be the fact that this indicator characterizes the ratio of equity to debt. If this indicator decreases, it means that the company has more free equity, which can be used to obtain more profit, which will increase the profitability of sales.

The asset turnover ratio is also related to the profitability of sales, as with its increase, the capital of the enterprise turns faster, therefore, each unit of the asset brings more profit.

When the inflation increases, the cost per unit of output does not increase, and the tariff is indexed, which leads to an increase in revenue.

With an increase in the refinancing rate, it is logical to assume that the company uses less borrowed funds, therefore, the share of own funds, which can be directed to obtain more profit increases, which will affect the profitability of sales.

The population and the number of apartments are directly related to the amount of energy consumed, which also affects the amount of profit.

The increase in return on sales is possible due the following reasons:

- Growth in sales;

- Changes in the product mix of sales.

With an increase in the number of products sold (in real terms), revenue increases faster than costs as a result of the so-called production leverage. Production leverage characterizes the share of fixed costs in total costs that are necessary for an economic entity to conduct operating activities, and is an important characteristic of the economic activity of the company [14-18].

Changing the cost structure can significantly affect the amount of profit. Investing in fixed assets is accompanied by an increase in fixed costs and theoretically, a decrease in variable costs. However, the relationship is non-linear, so it is not easy to find the optimal combination of fixed and variable costs.

The growth of profitability of sales with the growth of sales volume indicates an increase in the competitiveness of the company's services, due to factors such as quality, service in customer service, and not the price factor [19-21].

To improve profitability, we can offer a reduction of unnecessary costs, the development of a competent pricing policy, taking into account state regulation.

Thus, to ensure the efficiency of the electric power enterprise as a whole, the management of the organization should respond quickly to the restrictions created by the system of economic relations, manoeuvring financial resources and production programs. It is necessary to "develop immunity" to the influence of external and internal factors that violate the reproductive activities of the organization.

\section{References}

1. A. Afanas'ev, Financial stability factors of modern Russian electric power companies, Proceedings of BrSU Series: Economics and management, 60-63 (2017)

2. M. Cherutova, Problems of improving the financial performance of commercial organizations, Proceedings of the Bratsk state University. Series: Economics and management 147-150 (2017)

3. C. Xiuli, W. Zhenhua, W. Jian, A production information platform for electric power enterprise, Proceedings of the IEEE International Conference on Industrial Technology, 10.1109/ICIT.2008.4608547 (2008)

4. A. Dadayan, Comparative analysis of methods for assessing the financial stability of commercial organizations Economics and business: theory and practice, 9, 42-5 (2015)

5. A. Erastov, O. Novikova, Innovative energy saving: an integral method of assessing the motivational environment, Bulletin of Ivanovo state energy University, 2, 75-86 (2017)

6. A. Gorskin, Factors influencing the financial stability of the Corporation, Problems of modern science and education, 6(88), 37-42 (2017)

7. H. Yechu, Implementation of Responsibility Accounting in Electric Power Enterprises, 10.2991/icitme-18.2018.30 (2018)

8. J. Zhou, Y. Hu, Electricity Price Regulation and Electric Power Enterprises' Behaviors, International Journal of Business and Management, 6 (2011)

9. A. Kibitkin, Accounting and analysis in a commercial organization: tutorial, 368 (2012)

10. E. Kvyatkovskaya, Accounting for environmental factors in the methodology of financial analysis of enterprise sustainability, Forum of young scientists 11(15), 418-26 (2015)

11. W.C Liang, J.L. Luo, L. Zhong, Production elasticity and asset restructuring of electrical power enterprises, 34 (2001)

12. Y. Lyadova, Analysis of factors affecting the financial stability of the enterprise, and methods of their evaluation, The work of young scientists, 175-8 (2018)

13. N. Lyubushin, N. Babicheva, A. Galushkina, L. Kozlova, Analysis of methods and models for assessing the financial stability of organizations, ECONOMIC ANALYSIS, 1(166), 3-11 (2010)

14. F.H. Meng, M.W. Shi, Ch.M. Song, Research on Comprehensive Plan Management of Electric Power Enterprises, 10.2991/icmesd-18.2018.181. (2018)

15. K. Osipova, T. Kharlamova, The state of modern heat power engineering and increasing the economic efficiency of heat supply, International Scientific Conference on Energy, Environmental and Construction Engineering (EECE-2018) MATEC Web of Conferences, 245, https://doi.org/10.1051/matecconf/201824505002 (2018) 
16. D.G. Rodionov, E.A. Konnikov, O.A. Konnikova, Approaches to ensuring the sustainability of industrial enterprises of different technological levels, Journal of Social Sciences Research, 277282 (2018)

17. V.E. Shchepinin, V.A. Leventsov, B.F. Zabelin, E.A. Konnikov, E.O. Kasianenko, The content aspect of the tendency to reflect the actual result of management, 6th International Conference on Reliability, Infocom Technologies and Optimization (Trends and Future Directions) (ICRITO), 657-662, doi: 10.1109/ICRITO.2017.8342509 (2017)

18. E. Trunova, V. Alyab'eva, V, Factors and ways to improve the financial stability of organizations, 4 (2015)

19. A. Vasser, N. Kalajtan, Study of internal and external factors affecting the financial stability of enterprises and corporations, Science, education, business, 28-32 (2015)

20.Z. Li,ke, L. Kaibi, W.X. Shen, Research on Financial Risk Management for Electric Power Enterprises, Systems Engineering Procedia, 4, 5460, 10.1016/j.sepro.2011.11.049 (2012)

21.Z. Shipeng, Financial Management Innovation of Electric Power Enterprises Based on Robotic Process Automation, 10.2991/seiem-18.2019.53 (2019) 